\title{
EMPOWERING CIBOGO VILLAGERS, KABUPATEN TANGERANG, THROUGH EDUCATIONAL AND ENVIRONTMENTAL PROGRAM
}

Windarto WINDARTO ${ }^{1 *}$ and Martini MARTINI ${ }^{2}$

${ }^{1}$ Faculty of Information Technology, Budi Luhur University, Indonesia

${ }^{2}$ Faculty of Economics and Business, Budi Luhur University, Indonesia

*windarto@budiluhur.ac.id

\begin{abstract}
Community service is one of the higher education three pillars and aimed to increase social sensitivity to community problems so as to be able to contribute positively to regional development. Based on the results of initial observation in Cibogo Village, there are several problems that exist in the area, among others, are the lack of people in maintaining the cleanliness of their environment due to the lack of trashes can facilities around the environment and the lack of environmental education to the society. Human quality becomes a major issue and has an important role in the efforts of saving their own environment due to the human activities that do not consider continuity and environmental sustainability. It is impacting to degradation the environment quality which can affect too in many aspects. So it was decided to run some programs to improve facilities and infrastructure by providing some solutions to help the villagers solve their own environmental problems. One of which is environmental education program to foster the society to have a rational awareness and good behavior that is responsible to keep the environment clean and save. By the end, this community service activities is proposed to find out how to increase the awareness of the Cibogo villagers in maintaining a clean environment. It was found that the program to improve facilities and infrastructures that have been carried out has received a good response from the community, because it is very helpful to maintain their environmental cleanliness. Otherwise the education, skills, and creativity program were also received a good response from the children who have participated in the program.
\end{abstract}

Keywords: Community Service, Environment, Education, Infrastructure

\section{BACKGROUND}

To achieve sustainable urban development, cities must be planes and managed to form balance between human being a natural environtment by using resouirces carefully and transferring them to the next generatioins. Sutainability's applicability to three elements of life: nature, people, and business, as represented in Figure 1 (Mersal, 2016).

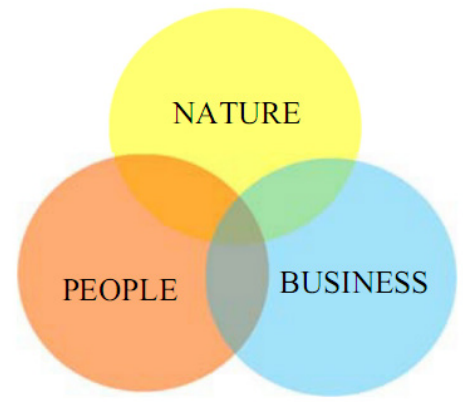

Figure 1. Three Elements of Sustainability

Waste can also be interpreted as a material that is wasted or thrown away from a result of human activity that is no longer used or is no longer desired, even waste has a negative value because of its handling, either to dispose or clean it requires a large cost. In addition, waste that is not handled properly can disturb environmental cleanliness, cause odors, and cause various diseases (Mustaghfiroh, et al., 2020). Due to the large impact of environmental problems due to waste, it is necessary to carry out proper management because waste disposal activities are endless (Kusumaningrum, et al., 2020). Waste management in urban areas is sometimes still very poor, such as in terms of land, engineering, and others. In urban environment, several obstacles or challenges are often encountered such as relatively low public awareness, especially those selling in the market, the lack of waste collection infrastructure, and the limited number of sanitation extension workers (Nizar, et al., 2013). The condition of society in developing countries contains a lot of variety of interests, including its relation to the awareness of environmental issues. On the one hand, there are still many people who look at issues of waste as something simple and do not need to be contemplated. On the other hand, the influence of the developed countries is very dominant. For example, rules on eco-labeling which demand furniture companies to prove that the raw materials are sourced from woodlands which are managed properly, can be said that it is the environmental impact of developed countries that cannot be avoided by developing countries, including the industry players in there (Winata, 2020).

Universitas Budi Luhur is a private university located in South Jakarta. Community service is one of the higher educational three pillars and aimed to increase social sensitivity to community problems so as to be able to contribute positively to regional development. On this occasion, the implementation of community service activities lasted for one month and took place around RT.011/RW.005 Cibogo Village, Cisauk District, Tangerang Regency. The activity took "empowering Cibogo villagers, Kabupaten Tangerang, through educational and environmental program" as a main theme. By hold these activities, Cibogo villagers, especially in RT.011/RW.005 are expected to be able to think creatively and be able to keep their environment clean.

\section{Problems}

1. How to increase awareness of Cibogo villagers in maintaining the cleanliness of their environment? 
2. What is the main role and relationship between university, the community, local government, and other related agencies so as to obtain feedback in order to increase the relevance of the higher education three pillars?

\section{Outputs}

1. Objectives

a. To find out how to increase the awareness of the Cibogo villagers in maintaining a clean environment.

b. To understand the community characteristics in their respective patterns of life.

c. To improve the relationship between university, the local government, and the community itself directly.

2. Benefits

a. To the community

i. The community have more insight to maintain their environment cleanliness.

ii. Gaining supports and assistances that can be used to develop the community.

iii. Acquiring knowledge and new perspectives on how the importance of maintaining environment cleanliness.

iv. Improve skills and creativity to children in Cibogo Village.

b. To the college

i. Establishing, expanding, and strengthening cooperation between the university and the related agencies.

ii. Obtaining the results of student activities, by hold study and formulate the state or conditions of the society that are useful for research development.

\section{METHODS}

The Community Service Program has been carried out on January 7 - January 30, 2021 in RT. 011/ RW. 005 Cibogo Village, Cisauk District, Tangerang Regency, Banten. In this program, two main programs were taken, namely the Improvement of Infrastructures and Facilities and Friendly to the Environment and to the Waste. First of all, survey the site to determine the location to put the trash cans. Then after, the society will be socialized how the importance of keeping the environment clean by disposing of domestic garbage in its place, and after all doing community service in a form of cleaning the environment around the neighborhood. The second program are skills and creativity. In this program, children aged around 4-11 years around the neighborhood have been invited to participate the program. The purpose of this program is to hone children's creativity. The third program is a supporting program consists of doing sports together. This activity was carried out to strengthen the bound of brotherhood between residents.

\section{RESULTS AND DISCUSSION}

The area of RT 011/RW 005 Cibogo Village is an area located in Cisauk District, Tangerang Regency, Banten Province. Located 2 kilometers away from Cisauk district office. Cibogo village has 411 hectares area consisting of 7 hamlets (RW) and 32 neighborhoods (RT). RT.011/ RW.005 consists of 4331 families. From their economic aspect, the majority of its residents in RT 011 make a living as private employees to Civil Servants (PNS). Another potential aspect they owned are some small industrial sectors (Source: AKA-TE'11).

1. Cibogo village area boundary:

North: Sampora Village

West: Cisauk Village

South: Suradita Village

East: Serpong District

2. There are several facilities and infrastructure in RT.011/RW.005:

a. Volleyball court

b. Badminton court

c. English and Mathematic Courses

d. Mosques

Based on observations and problems formulation which has been described previously, several programs can be formulated to solve those problems faced by residents in the neighborhood RT 011/RW 05 Cibogo village, as follows:

1. Facilities and Infrastructures for the Community

Table 1. Environmental Programs

\begin{tabular}{|c|c|c|c|c|}
\hline No. & Activities & Objectives & Targets & Venue \\
\hline 1. & $\begin{array}{l}\text { Trash Bin } \\
\text { Installation }\end{array}$ & $\begin{array}{l}\text { Remind the } \\
\text { residents to } \\
\text { dispose their } \\
\text { domestic waste } \\
\text { in its place to } \\
\text { maintain their } \\
\text { environment } \\
\text { clean. }\end{array}$ & $\begin{array}{l}\text { Children } \\
\text { Adults and } \\
\text { Parents }\end{array}$ & $\begin{array}{l}\text { Around the } \\
\text { neighborhood } \\
\text { of RT.011 }\end{array}$ \\
\hline 2. & $\begin{array}{l}\text { Communal } \\
\text { Work and } \\
\text { Clean } \\
\text { Environment } \\
\text { Socialization }\end{array}$ & $\begin{array}{l}\text { Remind the } \\
\text { residents to } \\
\text { maintain their } \\
\text { environment } \\
\text { clean. }\end{array}$ & $\begin{array}{l}\text { Children } \\
\text { Adults and } \\
\text { Parents }\end{array}$ & $\begin{array}{l}\text { Around the } \\
\text { neighborhood } \\
\text { of RT.011 }\end{array}$ \\
\hline
\end{tabular}

Education, Skills, and Creativity

Table 2. Educational Programs

\begin{tabular}{|c|c|c|c|c|}
\hline No. & Activities & Objectives & Targets & Venue \\
\hline 1. & $\begin{array}{l}\text { Drawing } \\
\text { Future } \\
\text { Dreams }\end{array}$ & $\begin{array}{l}\text { To educate } \\
\text { the children } \\
\text { about the } \\
\text { various } \\
\text { professions } \\
\text { exist. }\end{array}$ & Children & Class Room \\
\hline 2. & $\begin{array}{l}\text { Handy } \\
\text { crafting }\end{array}$ & $\begin{array}{l}\text { To increase } \\
\text { children's } \\
\text { creativity }\end{array}$ & Children & Class Room \\
\hline
\end{tabular}

Supporting Programs 
Table 3. Supporting Programs

\begin{tabular}{|c|c|c|c|c|}
\hline No. & Activities & Objectives & Targets & Venue \\
\hline 1. & Sports & $\begin{array}{l}\text { Remind the } \\
\text { residents to } \\
\text { maintain their } \\
\text { health by } \\
\text { applying healthy } \\
\text { living style. }\end{array}$ & $\begin{array}{l}\text { Teenagers and } \\
\text { Parents }\end{array}$ & $\begin{array}{l}\text { Volley } \\
\text { court and } \\
\text { badminton } \\
\text { court }\end{array}$ \\
\hline 2. & $\begin{array}{l}\text { Afternoon } \\
\text { Exercise }\end{array}$ & $\begin{array}{l}\text { Remind the } \\
\text { residents to } \\
\text { maintain their } \\
\text { health by } \\
\text { applying healthy } \\
\text { living style. }\end{array}$ & $\begin{array}{l}\text { Teenagers } \\
\text { and Parents } \\
\text { (women) }\end{array}$ & $\begin{array}{l}\text { Volley } \\
\text { court }\end{array}$ \\
\hline
\end{tabular}

\section{Main Program}

1. Type of Activity

The following activities has been carried out as a common program:

a. Community (infrastructure and facilities) installation of trash cans

b. Socialization and communal working

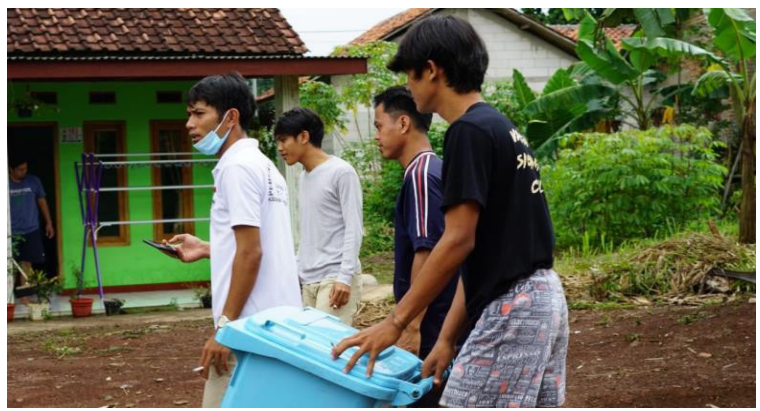

Picture 1. Environmental Program (Trash Cans Installation)

c. Education, skills, and creativity

a. Drawing future dreams

b. Handy crafting

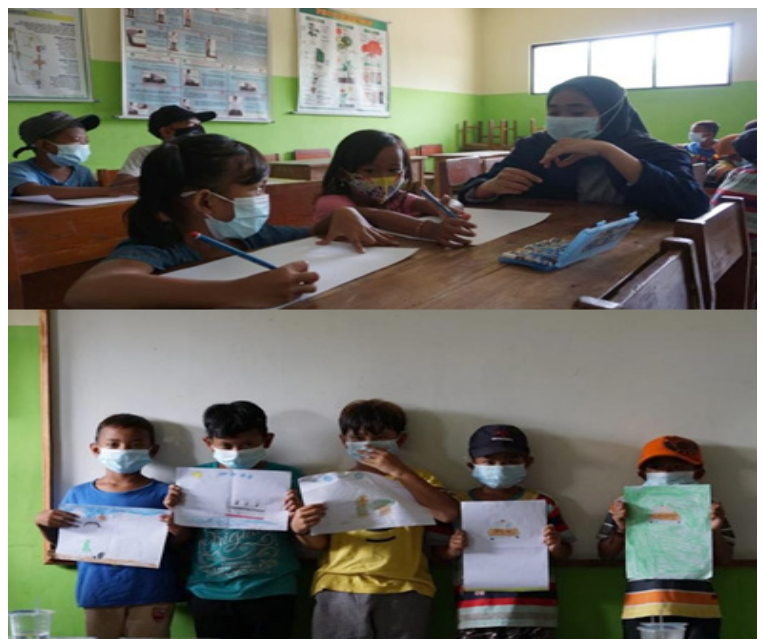

Picture 2. Educational Program for Children

2. Supporting and Obstacle Factors

a. Facilities and infrastructure

\section{i. Supporting factors}

The following are supporting factors for the facilities and infrastructure program, including: Enthusiasm of residents around the neighborhood RT.011 RW 05 supporting the whole programs listed.

Cleaning tools were provided in the neighborhood RT.011 RW 05, so there was no need to buy.

ii. Obstacle factors

The following are inhibiting factors for the facilities and infrastructure program, including a slight problem was found in placing the trash can due to undetermined spots of placing it.

b. Education, Skills, and Creativity

i. Supporting factors

The following are supporting factors for the education, skills, and creativity program, including:

Great enthusiasm from the children to participate in the whole activities.

Enthusiasm from the residents who always support and involved in all activities.

There was already a space in the area so that there is no difficulties in providing a place to do these activities such as drawing future dreams, and doing handy craft.

ii. Obstacle factors

The following are obstacle factors for the education, skills, and creativity program, including:

Less expertise of the participants in making crafts, so it takes more time to finish it.

Less enthusiasm of parents when their children participating in the activities being carried out.

c. Results and Follow Up

i. The results achieved in the facilities and infrastructure program is the trash bins installation in RT.011 RW.05 was successfully carried out so that people became more aware of the importance of disposing of their domestic waste in its place. The communal work in RT.011 RW.05 was successfully carried out so that the community became more aware of the importance of keeping their environment cleaner.

ii. Residents is expected to follow-up on facilities and infrastructure by using trash cans that has been installed previously to dispose their domestic waste and is expected they will always be able to keep their environment clean.

iii. The results achieved in educational programs, skills, creativity can be seen from the children in the environment who become more creative and increase their skills.

Community and the Local Government/Department/ Agency's support and participation were very good, breaks down as follow: 
1. Cibogo village management was very good by approving and fostering the activities that has been proposed to be realized.

2. Management of the neighborhood RT. 011 was also very good by approving and fostering the activities that has been proposed and they were very active in facilitating the whole activities.

3. The residents were very welcome in all programs carried out.

\section{Supporting Programs}

1. Type of activity is an afternoon gymnastics

a. Supporting and Obstacle Factors

i. Supporting factors

Tools and materials for supporting activities were easy to find and the whole community including mom and children were very enthusiastic in participating in the gymnastics activities held.

ii. Obstacle Factors

It was hard to gather the community and children to attend and participating in the programs and activities due to the COVID-19 pandemic which requires social distancing.

b. Results and Follow Up

i. Afternoon Gymnastics, it makes fit and healthy. Especially during this pandemic situation, it is hoped that the community's immune system will be grew stronger.

ii. It is hoped that the community can continue those activities and maintain to works the programs that has been carried out.

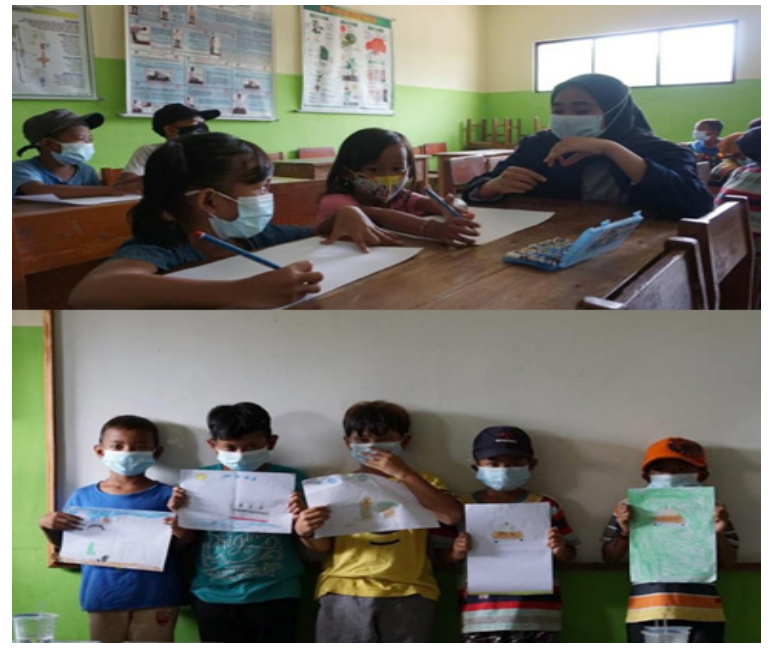

Picture 3. Supporting Program for Female Adults

c. Community Participation and Government Participation Community participation is very good in carrying out these supporting work program activities, the neighborhood's chief, village's chief and the community program's adviser were very helpful in implementing these programs.

d. Unfinished Activities

There is no supporting activities that have not been implemented.

\section{CONCLUSION}

Community service activities in RT 011/RW 05 Cibogo Village, Cisauk District, Tangerang Regency, Banten have been going well, and good responses and good attention from local residents have been received very well. The program to improve facilities and infrastructures that have been carried out has received a good response from the community, because it is very helpful to maintain their environmental cleanliness. The education, skills and creativity program were also received a good response from the children who have participated in this program, as well as the community who participated in supporting the program, because this program can helps the children to hone their skills. With this community service activity, hopefully the relationship between the university with the community and local government is growing better.

\section{REFERENCES}

AKA-TE'11, "Profil Desa." http://cibogocisauk.blogspot. com/p/data-demografi.html (accessed Sep. 04, 2021).

Kusumaningrum, L., et al. (2020). Comparison of Waste Management between Indonesia and South Korea. J. Glob. Environ. Dyn., 1(1), 13-19.

Mersal, A. (2016). Sustainable Urban Futures: Environmental Planning For Sustainable Urban Development. Procedia Environtmental Sciences 34, 49-61.

Mustaghfiroh, U., Sundusiyah, A., Addahlawi, HA., and Hidayatullah, AF. (2020). Implementasi Prinsip Good Environmental Governance dalam Pengelolaan Sampah di Indonesia. Bina Huk. Lingkung., 4 (2).

Nizar, M., Munir, E., and E. Munawar. (2013). Manajemen Pengelolaan Sampah Kota Berdasarkan Konsep Zero Waste : Studi Literatur. Pengabdi. Kpd. Masy., 7(2011), 93-102.

Noegroho, YAK., Noviyanti, S., Haryanto, JO., and Winata, L. (2019). A Model of Waste Management Improvement in Indonesia. Jurnal Akuntansi, 23(3), 393-408. doi: 10.24912/ja.v23i3.604. 